\title{
COVID-19-pandemian aiheuttaman poikkeustilanteen merkitys kokemusasiantuntijatoiminnalle mielenterveystyössä
}

COVID-19-pandemia keväällä 2020 sai aikaan nopeita ja mittavia muutoksia terveydenhuollossa. Toimintaa organisoitiin uudelleen, jotta pystyttäisiin turvaamaan riittävät resurssit testaamiseen ja tartunnan saaneiden hoitoon sekä minimoimaan tartuntariski. Muutokset ilmenivät myös psykiatrisessa erikoissairaanhoidossa. Tutkimuksen kontekstina oli sairaanhoitopiiri, jossa kokemusasiantuntijatoiminta on vakiintunut toimintamalli ammatillisen mielenterveystyön rinnalla. Tutkimuksessa selvitettiin poikkeustilanteen aiheuttamia muutoksia mielenterveystyön kokemusasiantuntijatoiminnassa, muutoksille annettuja merkityksiä sekä kokemusasiantuntijatoiminnan kehittämistarpeita. Aineistona olivat sairaanhoitopiirissä tehdyt fokusryhmähaastattelut mielenterveystyön ammattilaisille, kokemusasiantuntijoille ja asiakkaille. Aineisto kerättiiin kesän ja syksyn 2020 aikana osana laajempaa kokemusasiantuntijuuden merkityksiä tarkastelevaa tutkimusta. Aineisto on analysoitu laadullisen aineistolähtöisen sisällönanalyysin keinoin. Kokemusasiantuntijatoiminnassa COVID-19-pandemian aikana tapahtuneet muutokset konkretisoituivat kokemusasiantuntijoiden työtehtävissä. Kokemusasiantuntijatoiminnan muutosten merkitykset liittyivät sekä yksilö- että organisaatiotasolle. Yksilötasolla korostuivat vertaistuen toteutumiseen ja mielekkääseen toimintaan liittyvät merkitykset sekä taloudelliset ja tunnetason merkitykset. Organisaatiotasolla merkityksenannot liittyivät palvelujen monipuolisuuden vähenemiseen, kokemusasiantuntijakoulutuksen toteuttamiseen ja yhteistyön toteutumiseen. Kokemusasiantuntijatoiminnassa havaitut kehittämistarpeet kohdentuivat kokemusasiantuntijuuden jatkuvuuden ja monipuolisuuden varmistamiseen sekä etäpalveluiden kehittämiseen. Kokemusasiantuntijat kokivat sïrtymisen etätyöhön monin tavoin haasteellisena. Tutkimus nosti esiin tarpeen huomioida myös kokemustoimijoiden jaksaminen. Tutkimustulokset osoittivat, miten kokemusasiantuntijatoiminnan merkitys eri toimijoiden näkökulmasta korostui, kun toimintaa ryhdyttiin poikkeustilanteessa rajoittamaan. Tutkimus toi esiin kokemusasiantuntijatoiminnan kehittämistarpeita. Esille tuli myös toiminnan haavoittuvuus ympäristössä, jossa sillä on jo merkittävä ja vakïntunut asema. Mielenterveystyötä ohjaavat rakenteelliset tekijät ovat kokemusasiantuntijuuden tulevaisuuden kannalta laajempi yhteiskunnallinen kysymys.

ASIASANAT: mielenterveystyö, kokemusasiantuntijat, COVID-19

MARJATTA MARTIN, MINNA LAITILA, MARI KIVISTÖ, KARI SORONEN, SANNA HAUTALA 


\section{YDINASIAT}

I) mitä asiasta tiedettiin

- Kokemusasiantuntijatoiminta on merkittävässä roolissa mielenterveystyössä, mutta COVID-19-pandemian aikaisesta kokemusasiantuntijatoiminnasta ei ole aiempaa tutkittua tietoa.

2) mitä uutta tutkimus toi esille

- Tutkimus osoitti kokemusasiantuntijatoiminnan korostuneen merkityksen mielenterveystyössä pandemian kaltaisessa poikkeustilanteessa.

3) tutkimustulosten merkitys käytännössä

- Tuloksia voidaan hyödyntää mielenterveystyön ja kokemusasiantuntijatoiminnan kehittämisessä sekä pandemian aikana että sen jälkeen.

4) mitä tulisi tutkia tulevaisuudessa tästä aiheesta

- Tarvitaan tutkimusta mielenterveystyön kokemusasiantuntijatoiminnan toteutumisesta muissa konteksteissa pandemian aikana sekä pitkittäistutkimusta toiminnan muutoksista pandemian seurauksena.

\section{JOHDANTO}

Maailmanlaajuista COVID-19-pandemiaa voidaan kuvata vakavaksi, vaikeasti ennustettavaksi ja pitkäkestoiseksi kriisiksi, johon vastaaminen on haasteellista (1). Koronaviruspandemia sai keväällä 2020 aikaan nopeita ja mittavia muutoksia terveydenhuollossa vähentäen elektiivista hoitoa. Toimintaa organisoitiin uudelleen siten, että pystyttäisiin turvaamaan riittävät resurssit testaamiseen ja tartunnan saaneiden hoitoon sekä minimoimaan tartuntariski. Muutokset ilmenivät myös psykiatrisessa erikoissairaanhoidossa ja mielenterveystyössä. Etäpalvelujen osuus avohoitopalveluissa lisääntyi. Lähipalveluja, kuten terapiapalveluja, vertaisryhmiä ja matalan kynnyksen paikkoja, suljettiin ja etenkin ryhmämuotoinen toiminta kärsi sisällöllisesti tai keskeytyi kokonaan. (2-4.)

Koronavirukseen liittyvää lääketieteellistä tutkimusta on julkaistu jo paljon. Tutkimusta, jossa tarkasteltaisiin pandemian vaikutuksia mielenterveyteen ja mielenterveyspalveluihin, on tehty vähemmän. On arvioitu, että pandemia tulee vaikuttamaan mielenterveyteen niin koko väestön, terveydenhuollon henkilöstön kuin haavoittuvassa asemassa olevien väestöryhmien tasolla (5). Varhaisen vaiheen tutkimuksissa ja katsauksissa on havaittu pandemian heijastuneen mielenterveyteen muun muassa lisääntyneenä ahdistuksena, masennuksena ja stressinä sekä taloudellisina huolina $(6,7)$. Erityisesti niiden henkilöiden, joilla jo ennen pandemiaa oli mielenterveysongelmia, tilanteet näyttävät vaikeutuneen (8). Myös suomalaisten asiantuntija-arvioiden mukaan koronaviruspandemia ja siihen liittyvät rajoitustoimet ovat vaikuttaneet erityisesti niihin, jotka olivat jo ennen pandemiaa vaikeassa sosiaalisessa tilanteessa. Näitä ryhmiä ovat muun muassa mielenterveys- ja päihdekuntoutujat. (9, 10.) Kansainvälisissä ja kotimaisissa tutkimuksissa on kiinnitetty huomiota lisääntyneisiin mielenterveysoireisiin, yksinäisyyden kokemuksiin pandemian aikana sekä palveluihin pääsyn vaikeutumiseen etäpalveluihin siirryttäessä $(11,12)$.

COVID-19-pandemiaa on pidetty yhtäältä mahdollisuutena kehittää mielenterveystyön palvelujärjestelmää ja sen toimintatapoja tehokkaammiksi ja asiakaslähtöisemmiksi (7). Pandemian aikana tarve etäyhteyksiä hyödyntäville mielenterveyspalveluille on tullut vahvasti esille (8). Mielenterveyspalveluja onkin ryhdytty tarjoamaan aiempaa enemmän teknologiavälitteisesti, esimerkiksi videoneuvottelusovelluksia hyödyntäen. Etäpalvelut ja digitalisaatio voivat aikaansaada myönteistä kehitystä mielenterveyspalveluissa. Niiden avulla voidaan monipuolistaa palveluvalikoimaa esimerkiksi pitkien etäisyyksien alueilla. $(13,2$.) Osa mielenterveyspalvelujen käyttäjistä suhtautuu positiivisesti etäyhteyksien käyttöön, ja heille on tärkeää olla tarjolla myös digitaalisia palveluja $(14,4)$.

Toisaalta sähköisten palvelujen ja etäyhteyksien hyödyntämiseen liittyy haasteita. Etäyhteyksien käyttäjiksi on ohjattu myös sellaisia henkilöitä, jotka hyötyisivät enemmän kasvokkaisista palveluista (15). Vaikuttaa siltä, että etäpalvelut eivät ole olleet riittäviä vaikeimpiin mielenterveys- ja päihdeongelmiin vastaamiseksi $(2,16)$. Mielenterveyspalveluja käyttävillä henkilöillä ei välttämättä ole resursseja digitaalisten palvelujen käyttöön. Taloudellinen tilanne ei aina mahdollista laitteiden hankintaa. Myös digiosaamisessa voi olla puutteita tai kiinnostus laitteiden ja etäpalvelujen käyttämiseen voi olla vähäistä. $(3,10$.)

\section{KOKEMUSASIANTUNTIJATOIMINTA MIELENTERVEYSTYÖSSÄ}

Kokemusasiantuntijuutta tarkastellaan tässä tutkimuksessa erityisenä roolina, johon koulutus ja oman toipumisprosessin eteneminen antavat val- 
miudet $(17,18)$. Kokemusasiantuntijan tehtävät ovat palkka- tai palkkioperusteisia ja poikkeavat siksi perinteisestä vapaaehtoisesta vertaistoiminnasta. Kokemusasiantuntijan yhtenä tehtävänä on vertaistuen antaminen tukihenkilönä. Tällöin korostuu kokemusasiantuntijan kyky tukea asiakkaita yhteisten kokemusten pohjalta haasteellisten elämäntilanteiden käsittelyssä, vaihtoehtoisten ratkaisujen ja mahdollisuuksien etsimisessä sekä toivon ylläpitämisessä (19). Kokemusasiantuntijat toimivat myös kouluttajina ja osallistuvat yhdessä mielenterveystyön ammattilaisten kanssa ryhmänohjaukseen, asiakasvastaanottoihin, kotikäynteihin ja palvelujärjestelmän kehittämiseen (20). Kokemusasiantuntijat tuovat eri tehtävissään mielenterveystyöhön kokemuspohjaisen, asiakkaan ja osallistujan näkökulmaa avaavan ulottuvuuden.

Kokemusasiantuntijoiden ja ammattilaisten erilaisten tiedonlajien ja niiden erityisyyden tunnistaminen on tärkeää. Tutkimuksissa ammattilaisen ja kokemusasiantuntijan erilaista tietoa on kuvattu siten, että ammattilaisilla on mielenterveystyön sisällöllistä osaamista ja kokemusasiantuntijoilla tietoa palvelujärjestelmästä palvelunkäyttäjän näkökulmasta. Eroa sisällöllisen tiedon ja osaamisen sekä kontekstiin liittyvän asiantuntemuksen välillä on jäsennetty käsiteparilla content-context expertise $(21,22)$. Ammatillinen tieto ja kokemusperäinen tieto ovat yhdistettävissä jaetuksi asiantuntijuudeksi, jolloin kokemusasiantuntijuus saa tasaveroisemman aseman ammatillisen asiantuntijuuden rinnalla (23).

Kokemusasiantuntijatoimintaan kohdistuneessa tutkimuksessa on tarkasteltu toiminnan merkitystä sosiaali- ja terveyspalveluissa ja niiden kehittämisessä (24-27), kokemusasiantuntijoiden ja ammattilaisten yhteistyötä sairaalaorganisaatioissa ja mielenterveyspalveluissa (18, 28-30) sekä kokemusasiantuntijuuden merkitystä osallisuuden mahdollistajana ja toisaalta osallistamispolitiikan välineenä (31-33). Kokemusasiantuntijatoiminnan vaikutuksia tarkastelleet tutkimukset osoittavat, että toiminta edistää asiakkaan elämänhallintaa, hyvinvoinnin ylläpitämistä ja tyytyväisyyttä elämään $(34,35)$, kohentaa itseluottamusta ja elämänlaatua (27) sekä voi vähentää sairaalakäyntejä (36). Kokemusasiantuntijuuteen perustuvat palvelut koetaan myös myönteisinä vuorovaikutuksen, jaettujen kokemusten, henkilökohtaisuuden, toivon ja muutoksen mahdollisuuden korostumisen sekä tasaveroisuuden vuoksi (31). Ammattilaisten näkökulmasta kokemusasiantuntijatoiminta on koettu merkityksellisenä palvelujen asiakaslähtöisyyden, laadun ja tehokkuuden lisääntymisen kannalta (37). Kokemusasiantuntijatoiminnalla mielenterveystyössä on vahva kannatus, mutta se edellyttää ammattilaisten, johtajien ja muiden sidosryhmien tukea ja sitoutumista yhteistyöhön (27).

Kokemusasiantuntijoiden roolista tai vertaistuesta osana mielenterveystyön kokemusasiantuntijatoimintaa COVID-19-pandemian kontekstissa ei ole vielä julkaistu empiiristä tutkimusta. Sen sijaan tapauskuvauksissa $(38,39)$ on kiinnitetty huomiota poikkeusolojen aikaiseen ammattilaisten väliseen keskinäiseen tukeen, jota on kuvattu vertaistukena ja jossa on hyödynnetty myös etäyhteyksiä. On arvioitu, että mielenterveyspalveluissa on COVID-19-pandemian aikana vähennetty palvelunkäyttäjille tarjottavaa vertaistukea ja heidän osallisuuttaan lisääviä toimintoja (7). Digitaaliset välineet ja etäyhteydet voivat soveltua ja tarjota uusia mahdollisuuksia vertaistuen toteuttamiseen, mutta tämä edellyttää resursointia niin välineisiin kuin vertaistoimijoiden perehdytykseenkin $(40,41)$. Jo ennen pandemiaa todettiin, että vertaistoiminnan implementoinnin edellytyksenä on vertaistoimijoita tukeva organisaatiokulttuuri sekä vertaistoimijoiden pääsy organisaation resursseihin, kuten tietokoneille ja internetyhteyksiin (42). Lisäksi on tuotu esiin, että pandemian kaltaisissa kriisitilanteissa on muistettava myös vertaistoimijoiden merkitys ammattilaisten työn rinnalla ja heidän tarvitsemansa tuki (43). Siirtymisen puhelimitse tarjottuun vertaistukeen on kuvattu voivan olla hankalaa esimerkiksi tilanteissa, joissa vertaistukea on aiemmin tarjottu sairaalaympäristössä eivätkä vertaistoimijat koe saavuttaneensa riittävän läheisiä suhteita tuettaviensa kanssa voidakseen jatkaa yhteydenpitoa vastaavalla tavalla puhelimitse (44).

\section{TUTKIMUKSEN KONTEKSTI, TARKOITUS JA TUTKIMUSKYSYMYKSET}

Tämän tutkimuksen kontekstina on yksi sairaanhoitopiiri, jossa kokemusasiantuntijatoiminta on vakiintunut toimintamalli ammatillisen mielenterveystyön rinnalla. Kyseisessä sairaanhoitopiirissä kokemusasiantuntijakoulutusta ja -toimintaa on kehitetty yli kymmenen vuoden ajan. Koulutetut 
kokemusasiantuntijat työskentelevät monissa eri tehtävissä tukihenkilöinä asiakkaille ja potilaille aikuispsykiatrian osastoilla ja avohoidossa, vertaisohjaajina avohoidon ryhmissä ja sairaalan ryhmätoiminnoissa sekä koulutus- ja kehittämistyössä.

Tutkimuksessa tarkastellaan COVID-19-pandemian aikana tapahtuneita muutoksia kokemusasiantuntijatoiminnassa sekä muutoksille annettuja merkityksiä. Lisäksi kuvataan niitä kokemusasiantuntijatoimintaan liittyviä kehittämistarpeita, jotka tulivat esiin COVID-19-pandemian aikana. Tutkimuksessa vastataan seuraaviin kysymyksiin: 1) Millaisia muutoksia sairaanhoitopiirin kokemusasiantuntijatoiminnassa tapahtui COVID-19-pandemian aikana? ja 2) Millaisia merkityksiä ammattilaiset, kokemusasiantuntijat ja asiakkaat liittävät kokemusasiantuntijatoiminnassa tapahtuneisiin muutoksiin? sekä 3) Millaisia kokemusasiantuntijatoiminnan kehittämistarpeita havaittiin COVID-19-pandemian aikana?

\section{MENETELMÄT}

Tutkimukselle asetettuihin tavoitteisiin vastataan empiirisellä aineistolla, joka kerättiin yhdessä sairaanhoitopiirissä fokusryhmähaastatteluin. Haastattelut tehtiin kolmelle eri informanttiryhmälle: sairaanhoitopiirin psykiatrian toimintayksikön ammattilaisille (2 ryhmää), koulutetuille kokemusasiantuntijoille (2 ryhmää) ja avohoidon täysiikäisille asiakkaille (2 ryhmää). Aineistonkeruu toteutettiin kesän ja syksyn 2020 aikana. Haastattelut liittyvät laajempaan kokemusasiantuntijuuden merkityksiä tarkastelevaan tutkimukseen, ja niihin osallistui kaikkiaan 30 henkilöä (9 ammattilaista, 12 kokemusasiantuntijaa ja 9 asiakasta). Osallistujien valintakriteereinä olivat ammattilaisten kokemus yhteistyöstä kokemusasiantuntijoiden kanssa, avohoidon asiakkaiden osallistuminen kokemusasiantuntijoiden toteuttamaan toimintaan ja koulutettujen kokemusasiantuntijoiden toimiminen työtehtävissä.

Aineistonkeruumenetelmäksi valittiin fokusryhmähaastattelu, koska se mahdollistaa osallistujien yksilöllisiin kokemuksiin perustuvien merkitysten sekä heidän ryhmänä muodostamien merkityksenantojen tarkastelun (45). Ammattilaiset tuottivat merkityksiä oman työroolinsa, koulutetut kokemusasiantuntijat tehtäviensä ja asiakkaat asiakassuhteensa perusteella. Haastat- telujen toteutuksesta vastasi kaksi tutkijaa. Heistä toinen teki ensimmäisenä toteutetut kokemusasiantuntijoiden haastattelut ja toinen niitä seuranneet ammattilaisten ja asiakkaiden haastattelut. Haastatteluihin valmistauduttiin yhdessä keskustellen, ja haastattelurungot tehtiin yhteistyössä. Yhteistyöllä varmistettiin se, että fokusryhmissä keskustellaan samoista teemoista. Haastattelujen yhteiskesto oli yli 10 tuntia. Litteroitua haastatteluaineistoa kertyi kaikkiaan yli 200 sivua, josta COVID-19-pandemian ja kokemusasiantuntijatoiminnan yhteyteen kiinnittyvää aineistoa oli kaikkiaan 35 sivua.

Aineisto analysoitiin laadullisen aineistolähtöisen sisällönanalyysin keinoin $(46,47)$. Aineistolähtöinen sisällönanalyysi valittiin metodiksi, koska se soveltuu tilanteisiin, joissa olemassa olevia teorioita ja ilmiötä koskevaa tutkimuskirjallisuutta on rajallisesti (48). Analyysissä pyrittiin sulkemaan pois ennakkokäsitykset, päättely oli induktiivista ja analyysiyksiköiden valinta sekä ilmaisujen luokittelu tehtiin aineistolähtöisesti.

Analyysin ensimmäisessä vaiheessa aineistoa luettaessa kiinnitettiin huomio COVID-19-pandemiaan kohdistuviin haastattelujen osiin. Toisessa vaiheessa koottiin omiksi tiedostoiksi ammattilaisten, kokemusasiantuntijoiden ja asiakkaiden haastatteluista COVID-19-pandemiaan ja kokemusasiantuntijuuteen liittyvät aineisto-otteet. Tämän jälkeen tiedostojen aineisto ryhmiteltiin tutkimuskysymysten ohjaamana pandemian aikana kokemusasiantuntijatoiminnassa tapahtuneita muutoksia kuvaaviin ilmaisuihin, muutosten merkityksiin ja kehittämistarpeisiin liittyviin ilmaisuihin. Analyysiyksikkönä olivat alkuperäisilmaisujen kokonaisuudet ja toteamukset. Tämän jälkeen alkuperäisilmauksia pelkistettiin.

Seuraavaksi analyysissä muodostettiin ilmaisujen samankaltaisuuksien pohjalta alaluokkia. Esimerkiksi kokemusasiantuntijatoiminnassa tapahtuneita muutoksia kuvaavista ilmaisuista muodostettiin alaluokat: työskentelyn rajaaminen, ryhmätoiminnan rajoittaminen, vertaistukikeskustelut puhelimitse, kokemusasiantuntijatoiminnan vähentäminen ja tauottaminen sekä työtehtävien määrälliset ja sisällölliset muutokset. Tämän jälkeen samansisältöiset alaluokat yhdistettiin muodostaen yläluokkia, jotka nimettiin yleiskäsittein.

Kokemusasiantuntijatoiminnassa tapahtuneita muutoksia kuvaavat yläluokat nimettiin seu- 
raavasti: sairaanhoitopiirin linjaukset, henkilökohtaiset ratkaisut ja työtehtävien muutokset. Muutosten yksilöllisiä merkityksiä kuvaavat yläluokat muodostettiin samalla tavoin, ja ne nimettiin vertaistuen toteutumiseen, mielekkään toiminnan vähenemiseen ja uudelleen suuntautumiseen, taloudelliseen merkitykseen sekä tunnemerkityksiin. Muutosten organisatorisia merkityksiä kuvaavat yläluokat kiteytettiin palvelujen monipuolisuuden vähenemiseen, kokemusasiantuntijakoulutuksen toteuttamiseen sekä yhteistyön toteutumiseen. COVID-19-pandemian aikana havaitut kokemusasiantuntijatoiminnan kehittämistarpeet abstrahoitiin jatkuvuuteen ja monipuolisuuteen sekä etäpalvelujen kehittämiseen. Analyysin viimeisessä vaiheessa valittiin tehtyä luokittelua kuvaavia aineisto-otteita, joita suhteutettiin tutkimustehtävään, teoreettisiin jäsennyksiin ja muuhun tutkimukseen. Esimerkki aineiston analyysistä on kuvattu taulukkoon 1 .

Analyysin toteutuksen kahdesta ensimmäisestä vaiheesta vastasivat haastattelut tehneet tutki-

Taulukko 1. Kokemusasiantuntijatoiminnassa tapahtuneet muutokset: sairaanhoitopiirin linjaukset ja muutokset työtehtävissä esimerkkinä sisällönanalyysin etenemisestä.

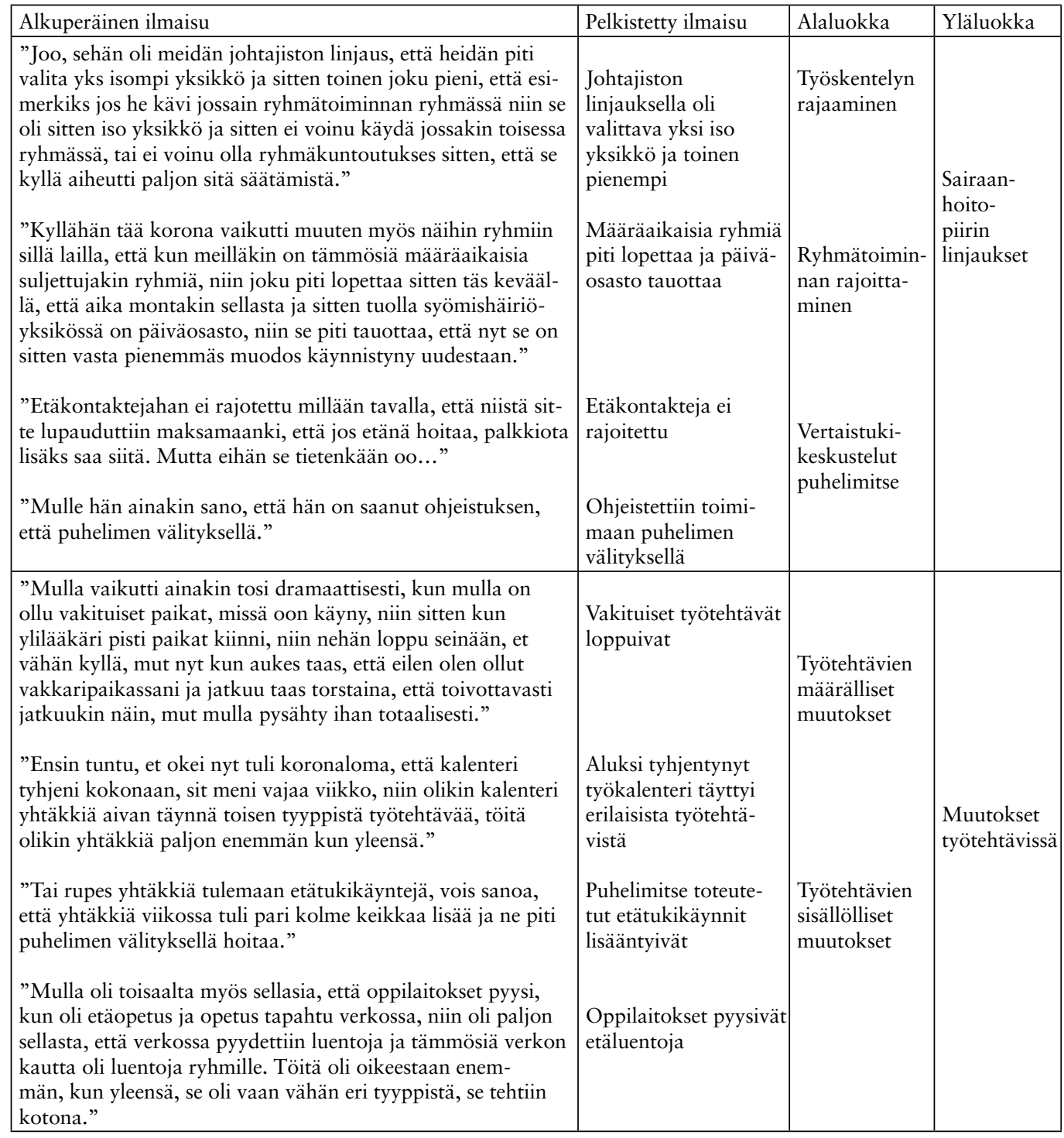


jat. Kolmannesta vaiheesta eteenpäin päävastuu oli yhdellä tutkijalla. Muut tutkimusryhmän jäsenet seurasivat analyysiprosessin etenemistä ja tehdyistä luokitteluista keskusteltiin yhdessä. Haastattelut tehneet tutkijat tarkistivat analyysin riittävyyden ja pyysivät mahdollisia täydennyksiä. Tehtyä ratkaisua pidetään yleisenä ja suositeltavana aineistolähtöisessä sisällönanalyysissä $(49,50)$. Analyysin luotettavuutta pyrittiin vahvistamaan tarkistamalla tehtyjen tulkintojen ja valittujen aineisto-otteiden edustavuus suhteessa koko aineistoon (51). Valitut aineisto-otteet identifioitiin tekstiin ryhmä- ja yksilötasolla, esimerkiksi ensimmäiseen kokemusasiantuntijoiden fokusryhmään osallistuneiden sitaatit on merkitty R1K1-R1K7 ja vastaavasti ammattilaisten/työntekijöiden haastatteluihin osallistuneet R3T1-R3T4 ja R4T1-R4T5. Täsmennykset on merkitty hakasulkeisiin [ ] ja poisjätöt sitaateissa väliviivoin - -.

Tutkimus toteutettiin hyvän tieteellisen käytännön ohjeita noudattaen (52). Eettinen ennakkoarviointi suoritettiin tutkimuksen toteuttajata- hon tutkimusta arvioivassa eettisessä neuvostossa, ja tutkimuslupa haettiin sairaanhoitopiiristä. Tutkimukseen osallistujia rekrytoitaessa tiedotettiin tutkimuksen tarkoituksesta, osallistumisen vapaaehtoisuudesta ja keskeyttämisen mahdollisuudesta, haastattelujen sisällöistä, tutkimusaineiston käytöstä ja luottamuksellisuudesta. Osallistujille toimitettiin vielä ennen haastattelujen toteutusta tietosuojaseloste, jossa kuvattiin tutkimushanke ja henkilötietojen käsittelyn tarkoitus. Tutkimukseen osallistuminen perustui informoinnin pohjalta annettuun tietoiseen kirjalliseen suostumukseen (53-55). Tutkimusaineistojen hankinnassa, käytössä ja analysoinnissa sekä tutkimustulosten raportoinnissa huomioitiin voimassa oleva normiohjaus, hyvä tieteellinen käytäntö sekä luottamuksellisuuden, yksityisyydensuojan ja loukkaamattomuuden periaatteet $(52,53)$.

\section{TULOKSET}

Tutkimuksen tulokset esitetään tiivistetysti tutkimuskysymyksittäin ja yläluokittain taulukossa 2 .

Taulukko 2. Keskeiset tulokset tutkimuskysymyksittäin ja yläluokittain.

\begin{tabular}{|c|c|c|c|}
\hline \multirow{2}{*}{$\begin{array}{l}\text { Kokemusasiantuntija- } \\
\text { toiminnassa tapahtuneet } \\
\text { muutokset }\end{array}$} & \multicolumn{2}{|c|}{$\begin{array}{l}\text { Kokemusasiantuntijatoiminnassa tapahtuneiden } \\
\text { muutosten merkitykset }\end{array}$} & \multirow{2}{*}{$\begin{array}{l}\text { Kokemusasiantuntija- } \\
\text { toiminnassa havaitut } \\
\text { kehittämistarpeet }\end{array}$} \\
\hline & Yksilötaso & Organisaatiotaso & \\
\hline $\begin{array}{l}\text { Sairaanhoitopiirin } \\
\text { linjaukset } \\
\text { - Työskentelyn } \\
\text { rajaaminen } \\
\text { - Ryhmätoiminnan } \\
\text { rajoittaminen } \\
\text { - Vertaistukikeskustelut } \\
\text { puhelimitse } \\
\end{array}$ & $\begin{array}{l}\text { Vertaistuen toteutuminen } \\
\text { - Saatavuus } \\
\text { - Sisältö } \\
\text { - Korvike muulle tuelle }\end{array}$ & $\begin{array}{l}\text { Palvelujen monipuolisuu- } \\
\text { den väheneminen } \\
\text { - Tukimuotoja } \\
\text { ja vaihtoehtoja } \\
\text { vähemmän } \\
\text { - Tuen tarpeen } \\
\text { ja palvelun } \\
\text { vastaamattomuus } \\
\end{array}$ & $\begin{array}{l}\text { Jatkuvuuden turvaaminen } \\
\text { - Vaihtoehtoiset } \\
\text { toimintamahdolli- } \\
\text { suudet } \\
\text { - Tiedottaminen }\end{array}$ \\
\hline $\begin{array}{l}\text { Henkilökohtaiset ratkaisut } \\
\text { - Toiminnan } \\
\text { vähentäminen } \\
\text { - Toiminnan } \\
\text { tauottaminen }\end{array}$ & $\begin{array}{l}\text { Mielekkään toiminnan } \\
\text { väheneminen ja uudelleen } \\
\text { suuntautuminen } \\
\text { - Vaihtoehtoisen } \\
\text { toiminnan etsintä } \\
\text { - Hyvinvointia } \\
\text { tukevaan toimintaan } \\
\text { suuntautuminen } \\
\text { - Tulevaisuuden } \\
\text { suunnitelmien } \\
\text { täsmentyminen } \\
\end{array}$ & $\begin{array}{l}\text { Kokemusasiantuntija-kou- } \\
\text { lutuksen toteuttaminen } \\
\text { - Toteutus etäyhteyksin } \\
\text { haastavaa } \\
\text { - Poikkeava } \\
\text { toteutustapa } \\
\text { kuormittava }\end{array}$ & $\begin{array}{l}\text { Monipuolisuuden varmis- } \\
\text { taminen } \\
\text { - Riittävä saatavuus } \\
\text { - Koulutus }\end{array}$ \\
\hline \multirow[t]{2}{*}{$\begin{array}{l}\text { Muutokset työtehtävissä } \\
\text { - Työtehtävien } \\
\text { määrälliset muutokset } \\
\text { - Työtehtävien } \\
\text { sisällölliset muutokset }\end{array}$} & $\begin{array}{l}\text { Taloudellinen merkitys } \\
\text { - Palkkioiden } \\
\text { ja korvausten } \\
\text { väheneminen } \\
\text { - Toimeentulon menetys }\end{array}$ & $\begin{array}{l}\text { Yhteistyön toteutuminen } \\
\text { - Jatkuvuus } \\
\text { - Työtehtävien } \\
\text { jakaminen }\end{array}$ & $\begin{array}{l}\text { Etäpalvelujen kehittäminen } \\
\text { - Resurssit } \\
\text { - Koulutus }\end{array}$ \\
\hline & $\begin{array}{l}\text { Tunnemerkitykset } \\
\text { - Rajoitusten } \\
\text { tarkoituksettomuus } \\
\text { - Etätyön } \\
\text { kuormittavuus }\end{array}$ & & \\
\hline
\end{tabular}




\section{COVID-I9-PANDEMIAN AIKANA TAPAHTUNEET MUUTOKSET KOKEMUSASIANTUNTIJATOIMINNASSA}

Kokemusasiantuntijatoiminnassa tapahtui COVID-19-pandemian aikana erilaisia muutoksia, jotka liittyivät taustaorganisaation ja yksittäisten henkilöiden päätöksiin. Toimintaan vaikuttivat sairaanhoitopiirissä tehdyt linjaukset ja asetetut rajoitukset, mutta myös yksittäisten kokemusasiantuntijoiden henkilökohtaiset ratkaisut. Muutokset konkretisoituivat kokemusasiantuntijoiden työtehtävissä.

Keväällä 2020 kokemusasiantuntijatoimintaa rajattiin sairaanhoitopiirin psykiatrian toimintayksikössä COVID-19-pandemian vuoksi siten, että kukin kokemusasiantuntija sai työskennellä vain kahdessa eri yksikössä. Näistä vain toinen saattoi olla niin sanottu suuri yksikkö, kuten psykiatrinen osasto, sairaalan ryhmätoiminnat, syömishäiriöyksikkö ja psykiatrian tehostettu avohoito.

”Joo, sehän oli meidän johtajiston linjaus, että heidän piti valita yks isompi yksikkö ja sitten toinen joku pieni, että esimerkiks jos he kävi jossain ryhmätoiminnan ryhmässä niin se oli sitten iso yksikkö ja sitten ei voinu käydä jossakin toisessa ryhmässä, tai ei voinu olla ryhmäkuntoutukses sitten - -.” (R3T2)

Psykiatrian toimintayksikön johtajiston päätöksellä välttämättömäksi arvioidut hoidolliset ja oireenhallintaryhmät saivat jatkaa toimintaansa. Ryhmän koon tuli olla alle 10 henkilöä, ja niissä tuli noudattaa sairaanhoitopiirin hygienia- ja suojainohjeita. Psykiatrian toimintayksikössä varauduttiin siihen, että tarvittaessa avohoito ja ryhmätoiminnot voitaisiin ajaa asteittaisesti alas ja siten turvattaisiin psykiatristen osastojen toiminta ja potilaiden psykiatrinen sairaalahoito sekä akuutti- ja päivystyksellinen toiminta.

”Kyllähän tää korona vaikutti muuten myös näihin ryhmiin sillä lailla, että kun meilläkin on tämmösiä määräaikaisia suljettujakin ryhmiä, niin joku piti lopettaa sitten täs keväällä, että aika montakin sellasta ja sitten tuolla syömishäiriöyksikössä on päiväosasto, niin se piti tauottaa - -.” (R3T2)

Työtehtäviä rajaamalla pyrittiin vähentämään kokemusasiantuntijoiden liikkuvuutta eri yksiköi- den välillä ja vaikuttamaan taudin leviämiseen. Etäyhteydellä hoidettavien työtehtävien määriä ei rajoitettu, vaan vertaistukikeskustelut ohjeistettiin hoitamaan puhelimen välityksellä.

"Etäkontaktejahan ei rajotettu millään tavalla, että niistä sitte lupauduttiin maksamaanki, että jos etänä hoitaa - -. ” (R4T4)

Sairaanhoitopiirin psykiatrian toimintayksikön kokemusasiantuntijatoiminnalle asettamien reunaehtojen lisäksi toimintaan vaikuttivat yksittäisten kokemusasiantuntijoiden omat ratkaisut. Osa vähensi kokemusasiantuntijatoimintaa tai jättäytyi siitä kokonaan pois pandemian aikana henkilökohtaisten syiden vuoksi.
”No, korona vaikutti - - se ryhmätoimintojen työtehtävä jäi pois, mut en mä ihan hirveen paljon olisi välttämättä tehny tänä aikana nii- tä työtehtäviä muutenkaan.” (R2K2)

Pandemian aikaiset muutokset konkretisoituivat kokemusasiantuntijoiden työtehtävissä sekä määrällisellä tasolla että niiden sisällöissä. Sairaanhoitopiirin psykiatrian toimintayksikön rajoitusten vuoksi työtehtävät vähenivät aluksi tai loppuivat kokonaan. Työtehtävissä saattoi myöhemmin tapahtua määrällistä kasvua, kun tehtävien toteutustapa ja sisällöt muuttuivat.

”Et kyllä siinä koronan seurauksena varmaan tommonen viis työtehtävää viikolta lähti pois. Joo, sellasta vakiotyötehtävää. Oisko ollu varmaan 80 prosenttia niin kun katos yhtäkkiä koronan seurauksena. - - Sit ne lisäänty niin hirveesti et alko tulee niitä etätöitä sitten kotiin. Just nää vertaistukipuhelut räjähti käsiin - -.” (R2K5)

Työtehtävien muutoksissa oli kokemusasiantuntijakohtaisia eroja, joihin vaikuttivat myös henkilökohtaiset ratkaisut vähentää tai tauottaa toimintaa. Kokemusasiantuntijoiden työtehtävissä tapahtui muutoksia myös siten, että tukihenkilöja vertaisohjaajatoiminnan vähentyessä lisääntyivät koulutukselliset tehtävät. Osalla kokemusasiantuntijoista painopiste sairaalassa tehtävästä työstä siirtyi oppilaitosyhteistyöhön. 
"Mulla oli toisaalta myös sellasia, että oppilaitokset pyysi, kun oli etäopetus ja opetus tapahtu verkossa, niin oli paljon sellasta, että verkossa pyydettiin luentoja ja tämmösiä verkon kautta oli luentoja ryhmille. Töitä oli oikeestaan enemmän, kun yleensä, se oli vaan vähän eri tyyppistä, se tehtiin kotona." (R1K3)

COVID-19-pandemian mukanaan tuomat rajoitukset vaikuttivat kokemusasiantuntijatoimintaan sairaanhoitopiirin psykiatrian toimintayksikön linjausten muodossa. Osa kokemusasiantuntijoista teki myös omia henkilökohtaisia ratkaisujaan, koska he pyrkivät välttämään tartuntoja ja niiden leviämistä sekä suojaamaan riskiryhmiin kuuluvia läheisiään. Vaikka sairaanhoitopiirin psykiatrian toiminta-alue koordinoi koulutettujen kokemusasiantuntijoiden välittämistä myös alueen kuntien ja kuntayhtymien sekä oppilaitosten tarpeisiin, niillä on mahdollisuus myös suoraan sopia työtehtävästä kokemusasiantuntijan kanssa. Tähän toimintaan eivät sairaanhoitopiirin COVID-19-pandemian vuoksi tekemät rajoitukset vaikuttaneet.

\section{KOKEMUSASIANTUNTIJATOIMINNASSA TAPAHTUNEIDEN MUUTOSTEN MERKITYKSET}

Kokemusasiantuntijatoiminnan muutosten merkitykset liittyivät sekä yksilö- että organisaatiotasolle. Yksilötasolla muutokset koettiin merkittävinä useiden eri elämänalueiden kannalta. Muutoksiin liitetyissä merkityksenannoissa korostuivat vertaistuen toteutuminen osana psykososiaalista tukea sekä mielekkään toiminnan väheneminen ja uudelleen suuntautuminen, taloudelliset ja tunnetason merkitykset. Organisaatiotasolla muutoksille annetut merkitykset liittyivät palvelujen monipuolisuuden vähenemiseen, kokemusasiantuntijakoulutuksen toteuttamiseen sekä yhteistyön toteutumiseen ammattilaisten ja kokemusasiantuntijoiden välillä.

Kokemusasiantuntijatoiminnassa tapahtuneet muutokset koettiin yksilötasolla merkityksellisinä vertaistuen toteutumisen kannalta useammasta eri näkökulmasta. Muutokset ensinnäkin vähensivät saatavan vertaistuen määrää ja toisaalta vaikuttivat sen toteutumistapaan. Kasvokkaiset kohtaamiset kokemusasiantuntijoiden kanssa vähenivät kauttaaltaan. Kokemusasiantuntijan poissaolo ryhmätoiminnoista vähensi osallistujien mahdollisuutta vertaistukeen ja yhteisen kokemuspohjan kautta muodostuvaan asioiden syvempään ymmärrykseen. Toisaalta asiakkaat kokivat etäyhteyksin toteutuvan vertaistuen merkitykselliseksi pandemian aiheuttamassa haastavassa tilanteessa, jossa psykososiaalisen tuen saaminen oli muutoin rajattua.

"-- Ja sillon koronakeväänä ku ei saanu [kokemusasiantuntija] tulla tänne meiän ryhmään, ni sen huomas heti sen laadullisen eron, että siellä tuli kyllä se asia siellä meiän ryhmässä mutta sitte se vertaistuki ja se oma ymmärrys jäi vähä ehkä puutteelliseksi ku ei ollu sitä kokemusasiantuntijaa paikalla." (R5A5)

"- - tän koronan aikaan niin soitin hänelle [kokemusasiantuntijalle] ihan henkilökohtasesti sitten kotoa ja siit oli tosi paljon apua, koska siinä tilanteessa oisin ollu aikalailla hukassa, koska ei näille kouluttajille [ammattilaisille] voi kun he tekee työtä täällä niin voi päivällä mitenkään soitella.” (R5A2)

Etäyhteyksien toimintavarmuus oli olennaista tuen saatavuuden ja vertaisuuteen perustuvien yhteisten kokemusten jakamisen kannalta. Ryhmätoimintoihin osallistuneet asiakkaat pettyivät kokoontumisissa, joihin kokemusasiantuntija ei voinut osallistua etäyhteyksien toimimattomuuden vuoksi. Etäyhteyksien koettiin ylipäätään soveltuvan joihinkin toimintoihin paremmin kuin toisiin, koska ne rajoittavat vuorovaikutusta osallistujien välillä.

”- - Et kylhän se aina vähän oli vähän semmonen et no toivottavasti se [kokemusasiantuntija] nyt ens kerralla on. Ja sit se kerta ku ei toiminu ne videoyhteydet ja sit se tietty pettymys siitä, että voi vitsi, että no ei se nyt ollukaan $\mathrm{ku}$ odotettu, et se nyt ois siellä videoitten päässä edes läsnä.” (R5A4)

Kokemusasiantuntijoiden työtehtävien väheneminen koettiin merkityksellisenä myös mielekkään toiminnan kannalta. Sekä kokemusasiantuntijat että ammattilaiset korostivat mielekkään tekemisen ja toiminnan vähenemistä kokemusasiantuntijatoiminnan rajoitusten vuoksi. Osa kokemusasiantuntijoista suuntautui ja aktivoitui vapaaehtoiseen potilasyhteisötoimintaan, kun he etsivät mielekästä tekemistä vähentyneiden 
kokemusasiantuntijatehtävien tilalle. Osalle kokemusasiantuntijoista työtehtävien väheneminen merkitsi alkuvaiheen hämmennyksen jälkeen huomion kiinnittämistä aiempaa enemmän omaa hyvinvointia tukevaan mieluisaan toimintaan. Kokemusasiantuntijan työtehtävien rajaus merkitsi myös sitä, että kokemusasiantuntijan omat tulevaisuuden suunnitelmat täsmentyivät. Rajoitusten myötä jäljelle jäänyt työtehtävä koettiin niin merkitykselliseksi, että tulevaisuudessa haluttiin keskittyä vastaaviin työtehtäviin. Kokemusasiantuntijan työtehtävien vähenemisellä koettiin olevan myös taloudellista merkitystä toimeentulon, palkkioiden ja korvausten menetyksinä, mikä korostui erityisesti ammattilaisten merkityksenannoissa.

”- - Oli se tietysti ensin hämmentävää, mut sitten kun senkin nyt vois ottaa niin että hei, nyt tässä on oikeesti niin kun aikaa. Että voi tehdä semmosta asiaa mitä tykkää. Pystyi kääntämään sen katseensa itseensä ja omaan hyvinvointiinsa. Niin tykkäsin siitäkin vielä, et siinä tuli sellanen huomio itteänsä kohtaan.” (R2K4)

”Eli kyllähän se heille elämä hiljeni, toiminta väheni, mutta myös taloudellisesti... Siitähän tulee palkkio ja matkakorvaus, niin myös ne jäi pois sitten kun ei ollu työtehtäviä. Että kyllä se heille sillä lailla näky - -.” (R3T4)

Tunnetasolla yksilölliset merkitykset liitettiin ensinnäkin kokemuksiin kokemusasiantuntijatoiminnan rajoitusten tarkoituksettomuudesta. Kokemusasiantuntijat totesivat toiminnalleen olevan vielä enemmän tarvetta pandemian aikana kuin normaalitilanteessa, minkä vuoksi palvelujen ei koettu rajoitusten myötä vastaavan olemassa oleviin tarpeisiin.

"Se on niin absurdi ajatus, että kokemusasiantuntijoiden tarve koronatilanteessa yhtäkkiä häviäis.” (R1K2)

"Katoais, että mulla oli ainakin se kokemus omien työtehtävien osalta, et ihmisten tarve kokemusasiantuntijoille, niin poikkeustila vaan kasvatti sitä. - -” (R1K1)

Kokemusasiantuntijatoiminnan rajoitusten tarkoituksettomuuteen liittyivät myös kokemukset rajoituksista eriarvoistavina. Ammattilaiset ku- vasivat omaa ja kokemusasiantuntijan asemaa lähtökohtaisesti tasaveroisina työyksikön jäseninä, mutta osa ammattilaisista oli kokenut pandemian aikana toteutuneet toimintamahdollisuudet eriarvoisiksi. Tilannetta pyrittiin ymmärtämään kokemusasiantuntijoiden muita laajemmalla liikkuvuudella sairaanhoitopiirin eri yksiköissä ja toiminnoissa sekä siihen liittyvällä tartuntaketjujen jäljittämisen haasteilla. Toisaalta ammattilaiset kokivat oman asemansa linjauksia tehneen sairaanhoitopiirin psykiatrian toimintayksikön johdon ja kokemusasiantuntijoiden välissä hankalaksi.

"Mun mielestä se oli eriarvoistava, siis hämmentävän eriarvoistava, että jos mun tiimin jäsenet, jossa me ollaan ihan tasa-arvosessa asemassa - - ei mulla käsittääkseni semmosta rajotetta ois ollu, että mää en ois voinu mennä vaikka tonne maakunnan polille - - heille [kokemusasiantuntijoille] asetettii. Ja mä, että mikä se tämmönen, mihin se pohjautuu?” (R4T3)

"Se pohjautu siihen lähinnä, että kokemusasiantuntijat kuitenki kulkee enemmän, enemmän ku esimerkiks varahenkilöstö kulkee täällä, et sitte se jäljittäminen ja se, et sillä pyrittii vähentään sitä. - - todella huonos välikädeshän siinä sitte jouduttiin, ja oli ylemmän tahon siinä, että yritti.” (R4T4)

Tunnetason yksilöllisissä merkityksissä korostui toisaalta etätyöhön liittyvä kuormittavuus. Kokemusasiantuntijoiden työtehtävien siirtyminen etäyhteyksin toteutettavaksi koettiin monella tapaa haasteelliseksi, vaativaksi ja rasittavaksi. Nonverbaalin viestinnän puuttuminen etäyhteyksin toteutettavasta tukihenkilötoiminnasta teki siitä kokemusasiantuntijoille vaativampaa ja kuormittavampaa kuin kasvokkaisista kohtaamisista. He arvioivat, että myös tuen tarvitsijoille haastavien elämäntilanteiden sanoittaminen oli vaativaa ilman kasvokkaista kohtaamista.

"- - Mutta haastavaa oli niissä puheluissa se, kun sä et oo face to face ihmisen kanssa, vaan puhut sen kanssa puhelimessa, niin et pysty näkemään ei-kielellistä viestintää. Joutuu koko ajan kuuntelemaan ja havainnoimaan äänensävyä, äänenpainoa, että ymmärsiköhän se nyt sen, mitä sanoin, loukkaantukohan se 
jostakin, jota sanoin, ja mua se ainakin kuormittaa aivan älyttömästi, on aivan poikki sen puhelun jälkeen, huh huh.” (R1K6)

"Ja usein sellaisessa tilanteessa ihmiselle, joka tarvii tukihenkilöä, niin se ei oo se sanallinen ulosanti välttämättä siinä elämäntilanteessa ihmiselle hirveän vahva. Et nonverbaalinen viestintä on tosi tärkeässä roolissa siinä tukihenkilötoiminnassa - -.” (R1K1)

Kokemusasiantuntijat pitivät etätyötä raskaana myös sen vuoksi, että rajat koti- ja työelämän välillä hämärtyivät. Työn tauottaminen unohtui ja luontaiset siirtymät tehtävän toteutuspaikasta toiseen jäivät pois. Toisaalta etäyhteydet eivät aina mahdollistaneet rauhallista tilannetta vertaistuelle. Ajan varaaminen työtehtävälle ja valmistautuminen tukihenkilönä toimimiseen aiheutti turhautumista silloin, kun tuen tarvitsijan ympäristö ei välttämättä ollutkaan suotuisa kokemusten jakamiseen sekä tuen antamiseen ja saamiseen etäyhteyksin.

"- - tuli sit se, että ei osannut rajata. Mun mielestä oli todella raskasta tehdä siellä kotona näitä videoyhteydellä sitten. Se oli paljon raskaampi olla siellä kotona sen näytön kanssa se työtehtävä, kun se että sä olisit ollu muualla. - - Sit unohdettiin pitää taukoja ja kaikkee tällasta. Mä en tykänny siitä ollenkaan et se työ tuli sitten kotiin, et kun se oli ollu aikasemmin niin et se työtehtävät on muualla ja kun meet kotiin ne jäi sinne. Nyt ne olikin koko ajan siinä. Se oli silleen tosi raskasta mun mielestä.” (R2K5)

”On käyny kans sillä tavalla, että vaikka ollaan sovittu potilaan kanssa, että soitan tiettynä aikana, että sovitaan ens viikon perjantai, et soitan. Sitten oon soittanu ja siellä on ollukin härdelli käynnissä ja ei siinä mitään, ollaan jouduttu lopettamaan puhelu siihen. Mut oon mä siltikin varannu tietyn ajan, et se on kuitenkin työaikaa, jonka oon varannu. Kyllä se ärsyttää - -.” (R1K6)

Organisaatiotasoon liittyvissä merkityksenannoissa korostui ensinnäkin palvelujen monipuolisuuden väheneminen. Kokemusasiantuntijatoiminnan rajoitusten koettiin vähentävän asiakkailta palveluvaihtoehtoja ja tukimuotoja. Rajoituksilla todettiin olevan merkitystä myös tarvittavan tuen ja annettavan avun vastaavuuden kannalta. Toisaalta kokemusasiantuntijan merkitys arvioitiin ylipäätään tärkeäksi palvelujen toteuttamisen ja niiden hyödyllisyyden kannalta. Osa asiakkaista toi tämän esiin korostamalla erityisesti kokemusasiantuntijoiden lisäarvoa ryhmätoimintojen toteuttamisessa.

"- - jos ajattelee potilasta niin palvelun monipuolisuus - - Että toki meillä oli kokemusasiantuntija, mutta että sitä palvelua tai mahdollisuuksia väheni, ettei ollu esimerkiks niitä yksilökäyntejä ei voinu sopia tai tämmösiä. Myös hoidossa olevalle henkilölle se yks mahdollisuus väheni siitä sitten, se kokemusasiantuntijan tuoma tieto ja kokemus ja läsnäolo.” (R3T4)

"Potilaiden näkökulmasta myös se, että kun ennen kävi useampia kokemusasiantuntijoita olemassa sen yhen päivän, niin oli tavallaan useammalle enemmän, tai sillai että kuitenkin siinä kokemusasiantuntijallakin on persoona niin paljon mukana, et joittenkin kans vaan klikkaa tai on samantyylisiä taustaa tai oireita tai muita ollut, niin sitten nyt kun kävi vaan kaks eri ihmistä, niin toki et sitten ehkä oli myös semmosia potilasryhmiä joille ei sitten kolahtanu, tai et eivät saaneet - - tukea heiltä." (R3T3)

Sairaanhoitopiirin psykiatrian toimintayksikön linjaukset koettiin merkityksellisinä myös kokemusasiantuntijakoulutuksen toteutuksen kannalta. Koulutuksen toteutus etäyhteyksin oli haasteellista, koska kaikilla osallistujilla ei ollut etäyhteyksiin tarvittavia välineitä. Koulutusta pidettiin myös osallistujia työllistävänä, koska he joutuivat tekemään pandemian aikana vaihtoehtoisia tehtäviä, kuten videoituja elämäntarinoita. Ammattilaiset olivat tämän vuoksi huolissaan kuntoutumispolkunsa alkuvaiheessa olevista koulutukseen osallistujista.

"Kokemusasiantuntijakoulutus on kärsiny, että se sitte etänä. - - kaikilla ei oo niitä laitteita, ei voida vaatia Skypeä, Teamsia, mitä näitä nyt onkaa. - - Mutta heihin on kans myös sillä lailla, et se on ollu työllistävää, koska he ovat tehneet korvaavia tehtäviä ja tehnyt elämäntarinoita kirjotettuna tai videona - -. Ja heistä, ku he eivät vielä ole valmiita ja sit se polku on 
kuitenki vasta siinä aika alussa, siinä koulutuksessa, että heistä on ollu sillai huolissaan enemmän kun näistä valmiista.” (R4T4)

Muutokset kokemusasiantuntijatoiminnassa aiheuttivat haasteita ammattilaisten ja kokemusasiantuntijoiden yhteistyön toteutumiselle sen jatkuvuuden ja työtehtävien jakamisen kannalta. Yhteistyön jatkuvuuden merkitys korostui tilanteissa, joissa työntekijät olivat tottuneet toimimaan yhdessä kokemusasiantuntijoiden kanssa. Toisaalta yhteistyön merkitys ilmeni myös asiakkaille niissä tilanteissa, joissa kokemusasiantuntijuus pyrittiin varmistamaan etäyhteyksin.

" - - myös sitten työntekijät, jotka olivat tottuneet tekemään töitä [yhdessä kokemusasiantuntijoiden kanssa], ei sitten yhtäkkiä saatukaan.” (R4T4)

”Nii ja sitte näillä meiän ohjaajilla ja sitte tällä kokemusasiantuntijalla, ainaki sai sen vaikutelman, on hyvä yhteistyö ja tällä tavalla ja hänethän otettiin sitte korona-aikaankin ku me oltiin ni sitten tuolta netin kautta tänne keskustelemaan kun hän ei voinu tulla meiän kanssa." (R5A4)

Ammattilaisten näkökulmasta ja heidän työnsä kannalta kokemusasiantuntijatoiminnan muutoksilla oli merkitystä esimerkiksi siten, että työtehtäviä ei voinut jakaa aiempaan tapaan vertaisohjaajana toimineen kokemusasiantuntijan kanssa. Toisaalta psykiatrian toimintayksikön ohjeistukset aiheuttivat laajemminkin haasteita kokemusasiantuntijatoiminnan yhteensovittamiseen ammatillisen mielenterveystyön rinnalle.

\section{COVID-19-PANDEMIAN AIKANA ESIIN TULLEET}

\section{KOKEMUSASIANTUNTIJATOIMINNAN KEHITTÄMISTARPEET}

COVID-19-pandemian aikana havaitut kehittämistarpeet kohdentuivat kokemusasiantuntijuutta hyödyntävien ja siihen perustuvien palvelujen jatkuvuuden turvaamiseen ja niistä tiedottamiseen. Lisäksi kehittämistarpeita todettiin olevan kokemusasiantuntijuuden monipuolisuuden varmistamisessa sekä etäpalveluissa.

Osa asiakkaista koki jääneensä ilman tarvitsemaansa vaihtoehtoista tukea, kun ryhmätoimintoja vähennettiin ja keskeytettiin pandemian vuoksi sairaanhoitopiirin linjauksilla. He kiinnittivät huomion siihen, että kasvokkaisiin kohtaa- misiin perustuvia ryhmätoimintoja ei korvattu etäyhteyksin toimivilla ryhmillä tai heille ei tarjottu mahdollisuutta kokemusasiantuntijan yksilölliseen vertaistukeen etäyhteyksin. Asiakkaat korostivat kokemusasiantuntijoiden merkitystä ryhmätoiminnoissa, ja moni toivoi tarpeisiinsa vastaavan palvelun jatkuvan heti tilanteen sen salliessa. Asiakkaiden kokemukset osoittavat, että matalan kynnyksen psykososiaalisen tuen jatkuvuuden varmistamiseen ja siitä tiedottamiseen tulee kiinnittää huomiota myös pandemian kaltaisissa poikkeustilanteissa.

"- - se [ryhmätoiminta] vaan loppu. Ei ollu mitään, et vähän siinä ite ootti, et ois nyt ollu joku video, itse asias oli vähän semmonen itellä, et no eikö nyt jotain ku kaikki tässä nyt tekee teamsia - - ja kaikkea mahollista, että eikö ny jotain ois voinu - -." (R5A4)

"Nii, se justiin se [kokemusasiantuntijan] puhelinhomma olis ollu varmaan ihan loistava, et ois voinu soittaa." (R5A5)

Kun kokemusasiantuntijoiden toimintamahdollisuudet kaventuivat sairaanhoitopiirin psykiatrian toimintayksikössä tehtyjen linjausten vuoksi ja heillä oli mahdollisuus työskennellä vain rajoitetusti eri yksiköissä, korostui tarve varmistaa kokemusasiantuntijuuden monipuolisuus. Tarvitaan eritaustaisia, koulutettuja sekä erilaisia valmiuksia ja taitoja omaavia kokemusasiantuntijoita riittävästi eri tehtäviin. Tähän kehittämistarpeeseen voidaan kiinnittää huomiota kokemusasiantuntijoiden koulutuksessa.

"- - kokemusasiantuntijoitten monipuolisuus on se minkä tossa huomasi, että miten tärkeää se on että niitä on monipuolisesti erilaisia kokemusasiantuntijoita.” (R3T3)

Kokemusasiantuntijuuteen perustuvien etäpalvelujen kehittämisessä todettiin tarpeelliseksi huomioida tietoturvallisen yhteydenpidon varmistaminen asiakastyössä, etäosallistumismahdollisuuksien laajentaminen sekä etäyhteyksien hyödyntämisen lisäämisen edellyttämät resurssit. Kokemusasiantuntijoiden puhelimitse asiakkaille tarjoaman vertaistuen lisäksi todettiin tarvittavan muita luotettavia ja tietoturvallisia yhteydenpitokanavia. Kokemusasiantuntijoiden etäosallistumismahdollisuuksia esitettiin kehitettävän 
paremmiksi myös siten, että he voivat osallistua erilaisiin ryhmätoimintoihin tarvittaessa etäyhteyksin.

”- - Että ehkä joku semmonen kanava pitää keksiä sitten heille, että pystyy jatkossa sitten olla paremmin suoraan yhteydessä potilaaseen luotettavilla yhteyksillä ja tietoturva pysyy hyvänä.” (R3T2)

"Varmaan se etäosallistumismahdollisuus paremmaksi, että sitten niin kun johonkin ryhmiin ja keskinäisiin - -. Että se ei olisi pelkästään se puhelinvälitteinen. Että kun meillä ammattilaisilla oli video connectia ja lync:iä ja kaikkia mahdollisia johonka tarvii sitten ne varmennekortit ja tunnukset ja tällaset, että sitten kun kokemusasiantuntijoilla ei ollu niitä - -. Et heillä oli niin kun sillai vaan sen puhelinyhteyden ja sitten kun jotkut Whatsappin videopuhelut ja tällaset ei oo luotettavia kanavia olla yhteydessä potilaaseen, et ne piti olla sillai suojattuja, niin sitten se oli niin kun toisin.” (R3T1)

Kehittämistarpeiden yhteydessä kiinnitettiin huomiota myös etäyhteyksien hyödyntämisen ja lisäämisen edellytyksenä tarvittavaan resursointiin, erilaisten sovellusten pilotointiin sekä tietoteknisen osaamisen kohentamiseen. Tutkimukseen osallistuneet ammattilaiset totesivat, että etäyhteyksien käyttöönotossa pandemian aikana oli haasteita, ja se vaati paljon työtä. Ammattilaisille järjestettiin pikakoulutusta tietoturvallisista sovelluksista ja niiden käytöstä. Kokemusasiantuntijoiden koulutusta ei pidetty mahdollisena tässä yhteydessä. Ammattilaiset kokivat etäpalvelujen kehittämisen olevan sairaanhoitopiirissä vielä alkuvaiheessa. Asiakkaille etäpalvelujen toteutumattomuus pandemian aikana näyttäytyi tietoteknisenä osaamattomuutena. Ammattilaisten ja asiakkaiden kokemusten perusteella etäpalveluissa on vielä paljon kehitettävää, jotta myös tietoturvalliset ja asiakkaiden tarpeisiin vastaavat kokemusasiantuntijoiden tarjoamat etäpalvelut ovat saatavilla.

\section{POHDINTA}

Tämä tutkimus on tiettävästi ensimmäisiä, joissa COVID-19-pandemian aiheuttaman poikkeustilanteen merkitystä tarkastellaan mielenterveystyön kokemusasiantuntijatoiminnan näkökulmas- ta. Tutkimuksessa selvitettiin poikkeustilanteen aiheuttamia muutoksia mielenterveystyön kokemusasiantuntijatoiminnassa, muutoksille annettuja merkityksiä sekä kokemusasiantuntijatoiminnan kehittämistarpeita. Tutkimuksen kontekstina toimi yksi sairaanhoitopiiri, jota voi luonnehtia kokemusasiantuntijatoiminnan edelläkävijäksi. Sairaanhoitopiirissä kokemusasiantuntijatoiminta on vakiintunutta ja mielenterveystyön käytäntöihin sisään rakentunutta. Siitä huolimatta koronaviruspandemiasta aiheutunut toiminnan uudelleen organisointi toi mukanaan merkittäviä muutoksia kokemusasiantuntijoiden työn kontekstiin (21).

Sairaanhoitopiirin kokemusasiantuntijatoiminta muuttui enemmän etäyhteyksin tapahtuvaksi, ja toiminnassa tärkeäksi koettuja lähikontakteja rajoitettiin eri tavoin. Kokemusasiantuntijoilla ilmeni jaksamiseen sekä työn tekemiseen liittyviä tuen tarpeita (42). Tutkimuksen kontekstina olleessa sairaanhoitopiirissä on kehitetty toimintakäytäntöjä kokemusasiantuntijoiden työssäjaksamisen tukemiseen esimerkiksi työnohjauksen avulla. Tulosten perusteella vaikuttaa kuitenkin siltä, etteivät tukitoimet olleet täysin riittäviä poikkeustilanteessa. Tutkimuksessa ilmenneet tarpeet (etä)työoloista huolehtimiseen, kokemusasiantuntijoiden tukemiseen, etätyön ja osaamisen kehittämiseen sekä selkeään viestintään ovat yhteneväisiä ammattilaisten esiin tuomien tarpeiden kanssa (56). Kokemukset etäyhteyksin toteutuvaksi muuttuneesta kokemusasiantuntijatoiminnasta olivat samansuuntaisia kuin aiemmat mielenterveystyöhön liittyvät havainnot: osa toimijoista sopeutui uusiin toimintatapoihin ja osa ei $(14,15,3,4)$.

Tutkimustulokset tekevät näkyväksi, miten kokemusasiantuntijatoiminnan merkitys eri toimijoiden - asiakkaiden, ammattilaisten ja kokemusasiantuntijoiden - näkökulmasta korostuu, kun toimintaa ryhdytään rajoittamaan. COVID19-pandemian aikana resurssit kohdennettiin akuuttihoitoon, tartuntariskien minimoimiseen ja tartuntaketjujen jäljittämiseen, mikä tarkoitti matalan kynnyksen palvelujen, ryhmätoimintojen ja psykososiaalisen tuen muotojen karsimista. Näiden tilalle sairaanhoitopiirissä tarjottiin muun muassa huolipuhelinta, johon osa asiakkaista ja kokemusasiantuntijoista soittikin. Tulosten perusteella vaikuttaa siltä, että palvelujen ei koettu täysin vastaavan olemassa oleviin tar- 
peisiin ja osa asiakkaista koki jääneensä ilman tarvitsemaansa ammatillista tukea. Tämä haaste on tunnistettu myös aikaisemmin kirjallisuudessa $(15,2,16,4)$. Näissä tilanteissa mahdollisuus kokemusasiantuntijan etäyhteyksin tarjoamaan vertaistukeen koettiin erittäin tärkeäksi, vaikka kasvokkaisista kohtaamisista arvioitiinkin olevan vielä enemmän hyötyä.

Terveydenhuollon ammattilaisten resurssien turvaaminen ja toimintojen uudelleen organisointi pandemian aiheuttamassa poikkeustilanteessa oli välttämätöntä. Samalla se toi esiin kokemusasiantuntijatoiminnan kehittämistarpeita ja haavoittuvuuden myös ympäristössä, jossa sillä on jo merkittävä ja vakiintunut asema. Mielenterveystyön säädöksiin pohjautuvat ammattilaisten asemaa, työn ehtoja ja työkulttuuria ohjaavat rakenteelliset tekijät korostuivat (57). Kokemusasiantuntijoiden toiminnan jatkuvuudesta huolehtiminen ja toimintakäytäntöjen turvaaminen ei toteutunut samalla tavoin kuin ammatillisten asiantuntijoiden. Muun muassa kokemusasiantuntijoiden pääsy tietokoneille ja toiminnalle tärkeisiin tietojärjestelmiin ei ollut mahdollista, mikä vaikeutti heidän työtään. Mielenterveystyötä ohjaavat rakenteelliset tekijät ovat kokemusasiantuntijuuden tulevaisuuden kannalta laajempi yhteiskunnallinen kysymys. Organisaatiokulttuurin muutoksella ja yhteistyöhön sitoutumisella on keskeinen merkitys kokemusasiantuntijoiden työn kehittymiselle ja tasa-arvoisemman aseman saavuttamiselle ammatillisten asiantuntijoiden rinnalla mielenterveystyössä (27).

COVID-19-pandemia voi olla myös mahdollisuus kehittää mielenterveystyötä asiakaslähtöisemmäksi (7). Tämän tutkimuksen tuloksissa korostuvat kokemusasiantuntijatoiminnan merkitys mielenterveystyössä sekä siinä olevat kehittämistarpeet. Kokemusasiantuntijatoiminta on itsessään arvokasta vertaistuen, kokemusten jakamisen ja toivon ylläpitämisen näkökulmasta $(31,37)$. Toisaalta se tukee ammatillista mielenterveystyötä, monipuolistaa palveluja ja mahdollistaa yhteistyötä $(18,28-30,37)$. Etäyhteyksien avulla voidaan lisätä palvelujen saatavuutta, mutta ne eivät sovellu kaikkeen toimintaan eivätkä kaikille asiakkaille. Tulokset vahvistavat ja täydentävät aiempia tutkimustuloksia $(2,15,16)$, ja niitä voidaan hyödyntää mielenterveystyön kehittämisessä.
Tämä tutkimus on poikkileikkaustutkimus ja sen konteksti on valikoitunut, mitä voidaan pitää sen heikkoutena. Tuloksia ei voida siten suoraan yleistää muihin kokemusasiantuntijatoiminnan konteksteihin. Tarkoituksena olikin tarkastella COVID-19-pandemian merkitystä mielenterveyden kokemusasiantuntijatoiminnassa sairaanhoitopiirissä, jossa kokemusasiantuntijatoiminta on jo integroitu osaksi työkäytäntöjä. Tutkimuksen vahvuutena voidaan pitää monipuolista aineistoa, jota kerättiin kokemusasiantuntijoilta itseltään, kokemusasiantuntijatoiminnan piirissä olevilta asiakkailta sekä kokemusasiantuntijoiden kanssa yhteistyötä tekeviltä ammattilaisilta. Aineiston ja valittujen menetelmien avulla pystyttiin vastaamaan asetettuihin tutkimuskysymyksiin. Jatkossa on tarpeen tutkia mielenterveystyön kokemusasiantuntijatoiminnan toteutumista pandemian aikana muissa sairaanhoitopiireissä ja toimintaympäristöissä. Lisäksi tarvitaan pitkittäistutkimusta siitä, muuttuuko kokemusasiantuntijatoiminta COVID-19-pandemian seurauksena.

\section{RAHOITTAJAT:}

ESR-rahoitteinen Recovery-toimintaorientaatio mielenterveyspalveluissa -hanke, jota hallinnoi Lapin yliopisto.

\section{KIRJOITTAJIEN KONTRIBUUTIOT:}

Martinilla oli päävastuu tutkimusasetelman suunnittelusta, analyysin toteutuksesta, menetelmien ja tulosten raportoinnista ja käsikirjoituksen eri versioiden kirjoittamisesta. Laitila kommentoi analyysia sen eri vaiheissa ja osallistui aineistosta analyysin perusteella tehtyjen tulkintojen tekoon, osallistui käsikirjoituksen kirjoittamiseen, sen kommentointiin eri vaiheissa vaikuttaen kirjoituksen sisältöön sekä hyväksyi käsikirjoituksen viimeisimmän version. Kivistö osallistui haastattelujen suunnitteluun, teki ammattilaisten ja asiakkaiden haastattelut ja niiden alkuvaiheen analyysit, osallistui analyysin myöhempien vaiheiden kommentoimiseen, käsikirjoituksen kirjoittamiseen ja sen kommentointiin eri vaiheissa vaikuttaen kirjoituksen sisältöön sekä hyväksyi käsikirjoituksen viimeisimmän version. Soronen osallistui haastattelujen suunnitteluun, teki kokemusasiantuntijoiden haastattelut ja niiden alkuvaiheen analyysit, osallistui analyysin myöhempien vaiheiden kommentoimiseen, käsikirjoituksen kirjoittamiseen ja sen kommentointiin eri 
vaiheissa vaikuttaen kirjoituksen sisältöön sekä hyväksyi käsikirjoituksen viimeisimmän version. Hautala osallistui haastattelujen suunnitteluun, kommentoi analyysia ja käsikirjoitusta sen eri vaiheissa vaikuttaen kirjoituksen sisältöön sekä hyväksyi käsikirjoituksen viimeisimmän version.

\section{Martin, M., Laitila, M., Kivistö, M., Soronen, K., Hautala, S. The significance of the state of exception caused by the COVID-19 pandemic for the work of experts-by-experience in mental health work. Sosiaalilääketieteellinen aikakauslehti - Journal of Social Medicine 202I: 58: 320-336.}

The coronavirus (COVID-19) pandemic in the spring of 2020 brought about rapid and far-reaching changes in health care. Operations were reorganised to ensure adequate resources for testing and caring for those infected and to minimise the risk of infection. These changes were also seen in psychiatric care.

The context of this study was a hospital district where the work of experts-by-experience is an established operating model alongside professional mental health work. The study examined the changes caused by the state of exception in the work of experts-by-experience, the meanings given to the changes and the development needs related to the work of experts-by-experience. The data were collected using focus group interviews conducted in the hospital district. The participants were mental health professionals, experts-by-experience and clients. The data were collected during the summer and autumn of 2020 as part of a larger study examining the meanings of experiential expertise. The analysis is based on inductive content analysis.

During the COVID-19 pandemic, changes in the work of experts-by-experience were concretised in their work tasks. The meanings given to the changes in the work of experts-by-experience were related to both the individual and organisational levels. The meanings connected to the implementation of peer support and meaningful activities, as well as the economic and emotional meanings, were highlighted as the individual-level meanings. At the organisational level, the meanings were related to the reduction in the diversity of services, the implementation of the training of experts-by-experience and the realisation of cooperation. The development needs identified in the work of experts-by-experience during the COVID-19 pandemic focused on ensuring the continuity and diversity of experiential expertise and the development of remote services.

The experts-by-experience found the transition to remote work to be challenging in many ways. This study highlighted the need to also consider the coping skills and well-being of experts-by-experience. The results showed how the significance of the work of experts-by-experience was emphasised by different actors in a situation where the work was narrowed down. The study pointed out the development needs of the work of experts-by-experience as well as its vulnerability in a context where it already has a significant and well-established position. The structural factors that guide mental health work are a broader societal issue for the future of experiential expertise.

Keywords: Mental health work, experts-by-experience, COVID-19

$$
\begin{array}{cc}
\text { Saapunut } & (10.03 .2021) \\
\text { Hyväksytty } & (18.08 .2021)
\end{array}
$$

\section{LÄHTEET}

(1) Pursiainen C. Kriisinhallinta ja koronakriisi: alustava arvio. Kosmopolis 2020;5:51-71.

(2) Partanen A, Suvisaari J. Päihde- ja mielenterveyspalvelut. Kirjassa: Kestilä L, Härmä V, Rissanen P (toim.) Covid-19-epidemian vaikutukset hyvinvointiin, palvelujärjestelmään ja kansantalouteen. Asiantuntija-arvio. Helsinki: THL 2020; Raportti 14/2020, 87-94.

(3) Jurvansuu S, Kaskela T, Tourunen J. Lähipalveluista sähköisiin etäpalveluihin. Päihdeja mielenterveysjärjestöjen työntekijöiden

kokemuksia koronapoikkeustilan aikana. Helsinki: Tietopuu Katsauksia ja näkökulmia 3/2020, A-klinikkasäätiö;2020:1-11.

(4) Laukka E, Gluschkoff K, Kaihlanen A-M, ym. Muutos psykiatristen avohoitokäyntien toteutuksessa ja johtajien kokemukset etäasiointia estävistä ja edistävistä tekijöistä COVID-19 aikakaudella . FinJeHeW 2021;13:49-62. doi: $10.23996 / f j h w .98228$ 
(5) Rajkumar RP. COVID-19 and mental health: a review of the existing literature. Asian J Psychiatr 2020;52:102066. doi: 10.1016/j.ajp.2020.102066

(6) Codagnone C, Bogliacino F, Gómez C, ym. Assessing concerns for the economic consequence of the COVID-19 response and mental health problems associated with economic vulnerability and negative economic shock in Italy, Spain, and the United Kingdom. PLoS ONE 2020;15:e0240876. doi: 10.1371/journal.pone.0240876

(7) Moreno C, Wykes T, Galderisi S, ym. How mental health care should change as consequence of the COVID-19 pandemic? Position paper. Lancet Psychiatry 2020;7:813-824. doi: 10.1016/S2215-0366(20)30307-2

(8) Newby J, O’ Moore K, Tang S, ym. Acute mental health responses during the COVID-19 pandemic in Australia. PLoS ONE 2020;15:e0236562. doi: 0.1371/journal.pone.0236562

(9) Kivipelto M, Karjalainen P, Partanen A, ym. Sosiaalisesti vaikeassa tilanteessa olevien työikäisten hyvinvointi. Kirjassa: Kestilä L, Härmä V, Rissanen P (toim.) Covid19-epidemian vaikutukset hyvinvointiin, palvelujärjestelmään ja kansantalouteen. Asiantuntija-arvio. Helsinki: Raportti 14/2020, THL; 56-63.

(10) Eronen A, Hiilamo H, Ilmarinen K, ym. Sosiaalibarometri 2020. Helsinki: SOSTE Suomen sosiaali ja terveys ry; 2020.

(11) Rissanen P, Parhiala K, Kestilä L, ym. COVID-19-epidemian vaikutukset väestön palvelutarpeisiin, palvelujärjestelmään ja kansantalouteen: nopea vaikutusarvio. Helsinki: THL; 2020.

(12) Sheridan Rains L, Johnson S, Barnett P, ym. Early impacts of the COVID-19 pandemic on mental health care and on people with mental health conditions: framework synthesis of international experiences and responses. Soc Psychiatry Psychiatr Epidemiol 2020;17:1-12. Epub ahead of print. PMID: 32804258; PMCID: PMC7429938. doi: 10.1007/s00127-020-01924-7

(13) Kuosmanen L. Covid-19-pandemia ja mielenterveys. Kirjassa: COVID-19-epidemian eettinen arviointi. ETENE-julkaisuja 47. Helsinki: Valtakunnallinen sosiaali- ja terveysalan eettinen neuvottelukunta ETENE ja STM. 2020, 40-41.

(14) Guinart D, Marcy P, Hauser M, ym. Patient attitudes toward telepsychiatry during the COVID-19 pandemic: a nationwide, multisite survey. JMIR Ment Health 2020;7:e24761. doi: $10.2196 / 24761$

(15) Chiauzzi E, Clayton A, Huh-Joo J. Videoconferencing-based telemental health: important questions for the COVID-19 era from clinical and patient-centered perspectives. JMIR Mental Health 2020;7:e24021. doi: $10.2196 / 24021$
(16) Jurvansuu S, Helfer A, Tourunen J ym. Muutokset järjestöjen tavoittamien ihmisten päihteidenkäytössä koronapoikkeustilan aikana. Toukokuussa 2020 toteutetun verkkokyselyn tuloksia. Helsinki: Tietopuu Katsauksia ja näkökulmia 4/2020, A-klinikkasäätiö; 2020:1-13.

(17) Beresford P. Public Participation in Health and Social Care: Exploring the Co-production of Knowledge. Front Sociol 2019;3:1-12. Luettu 18.1.2021. https://www.frontiersin.org/ articles/10.3389/fsoc.2018.00041/full doi: 10.3389/fsoc.2018.00041

(18) Hipp K, Vaajoki A, Kangasniemi M, ym. Kokemusasiantuntijan osallisuus mielenterveyspalvelujen kehittämisessä. Hoitotiede 2016;4:286-297.

(19) Järvikoski A, Martin M, Kippola-Pääkkönen A, ym. Asiakkaan kehittämisosallisuus kuntoutuksessa. Kirjassa Pohjola A, Kairala M, Lyly H, Niskala A. (toim.) Asiakkaasta kehittäjäksi ja vaikuttajaksi. Asiakkaiden osallisuuden muutos sosiaali- ja terveyspalveluissa. Tampere: Vastapaino; 2017, 58-81.

(20) McLaughlin H. What's in a name: "client", "patient", "customer", "consumer", "expert by experience", "service user" - what's next? Br J Soc Work 2009;39:1101-1117. doi: 10.1093/bjsw/bcm155

(21) Attygalle L. The context experts. A White Paper. Tamarack Institute 2017. Luettu 20.1.2021. https://www.mkekids.org/resources/decisionmakers/context-experts.html

(22) Williams G. Lay expertise. Kirjassa: Cockerham C, Dingwell R, Quah S (toim.) The WileyBlackwell encyclopedia of health, illness, behavior and society. Chichester: WileyBlackwell; 2014, 1283-1288.

(23) Soronen K. Kokemusasiantuntijoiden ja mielenterveystyön ammattilaisten jaettu asiantuntijuus mielenterveystyössä. Kirjassa Orjasniemi T, Romakkaniemi M, Tauro TM (toim.) Tutkiva sosiaalityö. Muuttuvat rajat ja vastuut - globaali ja lokaali sosiaalityössä. Helsinki: Talentia ry ja Sosiaalityön tutkimuksen seura; 2019, 115-128.

(24) Ahola M. Vaikuttaminen kokemuksellisen asiantuntijuuden ytimenä. Kirjassa: Pohjola A, Kairala M, Lyly H, Niskala A. (toim.) Asiakkaasta kehittäjäksi ja vaikuttajaksi. Asiakkaiden osallisuuden muutos sosiaali- ja terveyspalveluissa. Tampere: Vastapaino; 2017, 286-307.

(25) Jones M. Kokemustiedon määritykset ja käyttö julkisen terveydenhuollon kontekstissa. Kirjassa: Toikkanen J, Virtanen I. (toim.) Kokemuksen tutkimus VI: kokemuksen käsite ja käyttö. Rovaniemi: Lapland University Press; 2018, 169-190.

(26) Muurinen H. Service-user participation in developing social services: applying the experiment-driven approach. European Journal of Social Work 2019;22:961-973. doi: 10.1080/13691457.2018.1461071 
(27) Shalaby RAH, Agyapong VIO. Peer support in mental health: literature review. JMIR Ment Health 2020;7:e15572.

doi: $10.2196 / 15572$

(28) Haapakoski K, Kasila K, Kettunen T. Tunnesidonnainen toiminnan säätely ja kokemusasiantuntijoiden sisäänpääsy sairaalaorganisaatioon. Päiväkirja-analyysin yhtymäkohdat Norbert Eliasin teoriaan. Janus 2018;26:40-56. doi: 10.30668/janus.64210

(29) Otte I, Werning A, Nossek A, ym. Challenges faced by peer support workers during the integration into hospital-based mental healthcare teams: results from a qualitative interview study. Int J Soc Psychiatry 2020;66:263-269. doi: 10.1177/0020764020904764

(30) Soronen K. Arvioivan katseen alla vai aitoa yhteistyötä? Kokemusasiantuntijoiden positioiden rakentuminen päihde- ja mielenterveystyössä. Helsinki: Tietopuu Tutkimussarja 1/2021, A-klinikkasäätiö;2021:1-23. doi: 10.19207/TIETOPUU9

(31) Bochicchio L, Stefancic A, McTavish C, ym. "Being there" vs "being direct": perspectives of persons with serious mental illness on receiving support with physical health from peer and non-peer providers. Adm Policy Ment Health 2021;48:539-550.

doi: 10.1007/s10488-020-01098-z

(32) Meriluoto, T. "The will to not be empowered (according to your rules)": resistance in Finnish participatory social policy. Crit Soc Policy 2019;39:87-107. doi: $10.1177 / 0261018318764322$

(33) Palukka H, Tiilikka T, Auvinen P. Kokemusasiantuntija sosiaali- ja terveyden huollon palvelujärjestelmässä - osallisuuden mahdollistaja vai osallistamispolitiikan edustaja. Janus 2019;27:21-27. doi: $10.30668 /$ janus.66252

(34) Cook J, Copeland ME, Corey L, ym. Developing the evidence base for peer-led services: changes among participants following Wellness Recovery Action Planning (WRAP) education in two statewide initiatives. Psychiatr Rehabil J 2010;34:113-120. doi: $10.2975 / 34.2 .2010 .113 .120$

(35) Davidson L, Bellamy C, Guy K, ym. Peer support among persons with severe mental illness: a review of evidence and experience. World Psychiatry 2012;11:123-128. doi: 10.1016/j.wpsyc.2012.05.009

(36) Wright-Berryman J, McGuire A, Salyers M. A review of consumer-provided services on assertive community treatment and intensive case management teams: implications for future research and practice. J Am Psychiatr Nurses Assoc 2011;17:37-44. doi: $10.1177 / 1078390310393283$

(37) Kivistö M, Martin M, Hautala S. Ammattilaisten antamat merkitykset mielenterveys- ja päihdetyöhön integroidulle kokemusasiantuntijatoiminnalle toipumisen tukemisessa. Helsinki: Tietopuu Tutkimussarja 2/2021, A-klinikkasäätiö;2021:1-18. doi: 10.19207/TIETOPUU10

(38) Cheng P, Guohua X, Peng P, ym. COVID-19 epidemic peer support and crisis intervention via social media. Community Ment Health J 2020;56:786-792. doi: 10.1007/s10597-020-00624-5

(39) Viswanathan R, Myers MF, Fanous AH. Support groups and individual mental health care via videoconferencing for frontline clinicians during the COVID-19 pandemic. Psychosomatics 2020; 61:538-543. doi: 10.1016/j.psym.2020.06.014

(40) Fortuna KL, Myers AL, Walsh DBS ym. Strategies to increase peer support specialists capacity to use digital technology in the era of COVID-19: pre-post study. JMIR Mental Health 2020a; 7:e20429. doi: $10.2196 / 20429$

(41) Fortuna KL, Naslund JA, LaCroix JM, ym. Digital peer support mental health interventions for people with a lived experience of a serious mental illness: systematic review. JMIR Ment Health 2020b;7:e16460. doi: $10.2196 / 16460$

(42) Ibrahim N, Thompson D, Nixdorf R, $y m$. A systematic review of influences on implementation of peer support work for adults with mental health problems. Soc Psychiatry Psychiatr Epidemiol 2019;55:285-293. doi: 10.1007/s00127-019-01739-1

(43) Fisher EB, Miller SM, Evans M, ym. COVID-19, stress, trauma, and peer support -observations from the field. Transl Behav Med 2020;10:503505 . doi: 10.1093/tbm/ibaa056

(44) Mpango, R., Kalha, J., Shamba, D, ym. Challenges to peer support in low- and middle-income countries during COVID-19. Globalization and health 2020;16:90. doi: 10.1186/s12992-020-00622-y

(45) Pietilä I. Ryhmä- ja yksilöhaastattelun diskursiivinen analyysi. Kaksi aineistoa erilaisina vuorovaikutuksen kenttinä. Kirjassa: Ruusuvuori J, Nikander P. (toim.) Haastattelun analyysi. Helsinki: Vastapaino 2010, 212-241.

(46) Graneheim UH, Lundman B Qualitative content analysis in nursing research: concepts, procedures and measures to achieve trustworthiness. Nurse Educ Today 2004;24:105-112.

(47) Tuomi J, Sarajärvi A. Laadullinen tutkimus ja sisällönanalyysi uud. p. Helsinki: Tammi; 2018.

(48) Hsieh H-F, Shannon S. Three approaches to qualitative content analysis. Qual Health Res 2005; 15:1277-1288. doi: $10.1177 / 1049732305276687$

(49) Kyngäs H, Elo S, Pölkki T, ym. Sisällönanalyysi suomalaisessa hoitotieteellisessä tutkimuksessa. Hoitotiede 2011;23:138-148. 
(50) Elo S, Kääriäinen M, Kanste O, ym. Qualitative Content Analysis: a focus on trustworthiness.

SAGE Open 2014;4:1-10.

doi: $10.1177 / 2158244014522633$

(51) Thomas E, Magilvy JK Qualitative rigour or research validity in qualitative research. J Spec Pediatr Nurs 2011;16:151-155. doi: 10.1111/j.1744-6155-2011.00283.x

(52) Tutkimuseettinen neuvottelukunta. Hyvä tieteellinen käytäntö ja sen loukkausepäilyjen käsitteleminen Suomessa. Tutkimuseettisen neuvottelukunnan ohje 2012. Luettu 14.1.2021. HTK_ohje_2012.pdf (tenk.fi)

(53) Kuula A. Tutkimusetiikka. Aineistojen hankinta, käyttö ja säilytys. Helsinki: Vastapaino; 2006.

(54) Mäkinen O. Tutkimusetiikan ABC. Helsinki: Tammi; 2001.

(55) Ryen A. Ethics and qualitative research. Kirjassa: Silverman D (toim.) Qualitative research. Los Angeles: SAGE; 2011, 416-438.

(56) McFadden P, Gillen P, Moriarty J, ym. Health and social care workers` quality of working life and coping while working during the Covid-19 -pandemic: analysis of positive coping and workrelated quality of life as resilience and protective factors impacting on wellbeing. Conference contribution. In The 3rd International Electronic Conference on Environmental Research and Public Health: Public Health Issues in the Context of the COVID-19 Pandemic: Proceedings 2021.

(57) Miettinen R, Romakkaniemi M, Laitinen M. Historialliset painolastit asiakkaan aseman haastajina. Kirjassa: Pohjola A, Kairala M, Lyly H, ym. (toim.) Asiakkaasta kehittäjäksi ja vaikuttajaksi - Asiakkaiden osallisuuden muutos sosiaali- ja terveyspalveluissa. Tampere: Vastapaino; 2017, 15-37.

Marjatta Martin

YTT, tutkimuspäällikkö

Lapin yliopisto

Yhteiskuntatieteiden tiedekunta

Minna Laitila

TtT, YTM, lebtori

Seinäjoen ammattikorkeakoulu

MARI Kivistö

YTT, yliopistonlehtori

Lapin yliopisto

Yhteiskuntatieteiden tiedekunta

KARI SORONEN

YTM, KM, tutkija

Lapin yliopisto

Yhteiskuntatieteiden tiedekunta

Sanna Hautala

sosiaalityön professori

Lapin yliopisto

Yhteiskuntatieteiden tiedekunta 